STUDIA HISTORICA GEDANENSIA

TOM XII (2021)

\author{
Michał Kosznicki \\ (Uniwersytet Gdański) \\ https://orcid.org/0000-0003-1503-6981
}

\title{
Epidemie i pandemie w wybranych polskich podręcznikach szkolnych historii dla szkół średnich po 1989 r.
}

Słowa kluczowe: epidemie, historia, podręczniki szkolne Keywords: epidemics, history, school textbooks

Doświadczenia współczesnej pandemii w naturalny sposób stawiają pytania o dotykające ludzkość wielkoskalowe zagrożenia naturalne, przede wszystkim biologiczne i medyczne. Kierują one również uwagę w stronę przeszłości, a więc doświadczeń minionych pokoleń, czasowo przesłoniętych przez gwałtowny postęp cywilizacyjny, które dramatycznie zmagały się z różnorodnymi klęskami naturalnymi, a w szczególności masowymi zachorowaniami wywołanymi przez czynniki zakaźne. Niektóre z tych epidemii wywarły znaczący wpływ na bieg historii, jak też odcisnęły trwałe piętno na różnorodnych dziedzinach życia społecznego ${ }^{1}$. W dziejach europejskich społeczeństw szczególną rolę odegrała wielka epidemia tzw. czarnej śmierci z połowy XIV w., a dla autochtonicznych społeczeństw Nowego Świata katastrofalne znaczenie miały lokalne epidemie z XVI w. spowodowane przybyciem hiszpańskich konkwistadorów. Charakter pandemiczny miała epidemia grypy, tzw. hiszpanki, która przetoczyła się praktycznie przez cały świat po zakończeniu I wojny światowej. Niektóre z tych zjawisk, ze względu na swoje znaczenie czy też doniosłość dziejową, stały się częścią przekazu dydaktyczno-historycznego,

1 Ogólnie na temat epidemii i pandemii w dziejach świata zob. Jacques Ruffié, Jean Ch. Sournia, Historia epidemii: od dżumy do Aids, tłum. B.A. Matusiak (Warszawa: Wydawnictwo W.A.B., 1996); Epidemie w dziejach Europy: konsekwencje społeczne, gospodarcze i kulturowe, red. Krzysztof Polek, Łukasza T. Sroka (Kraków: Wydawnictwo Naukowe Uniwersytetu Pedagogicznego, 2016); Frederick F. Cartwright, Michael Biddiss, Niewidzialny wróg: zarazy i historia, tłum. M. Wyrwas-Wiśniewska (Warszawa: Wydawnictwo Wołoszański, 2005); Christopher Duncan Susan Scott, Czarna śmierć. Epidemie w Europie od starożytności do czasów współczesnych, tłum. A. Siennicka (Warszawa: Wydawnictwo Bellona, 2008). 
realizowanego w polskich szkołach na różnych etapach kształcenia, przede wszystkim na poziomie średnim.

W obrazie przeszłości współkreowanym przez szkołę istotną rolę spełniają podręczniki szkolne, które nadal - pomimo rozwoju nowoczesnych form przekazu odgrywają dominującą rolę pośród środków dydaktycznych wykorzystywanych na lekcjach ${ }^{2}$. Celem podjętego badania było sprawdzenie, jak największe pandemie i epidemie $\mathrm{w}$ dziejach ludzkości zostały przedstawione w narracjach podręcznikowych po 1989 r. Niniejszy artykuł jest próbą odpowiedzi na zasadnicze pytania badawcze: jaki obraz największych pandemii i epidemii otrzymali (i otrzymują) polscy uczniowie szkół średnich w podręcznikach szkolnych do historii w ostatnich 32 latach? W jakim zakresie wspomniane zagadnienia zostały przedstawione $\mathrm{w}$ formie przekazu narracyjnego (tylko tekstu autorskiego), a w jakim obudowane dodatkowymi elementami dydaktycznymi (ikonografią, ćwiczeniami itp.)? Badaniu podlegał nie tylko sposób prezentacji interesującej nas tematyki, ale także kontekst zademonstrowania samych wydarzeń. Przedmiotem analizy były wybrane podręczniki do historii dla szkół średnich, tj. ponadgimnazjalnych i ponadpodstawowych, wydane po $1989 \mathrm{r}$. w tzw. wersjach podstawowych, rozszerzonych, podstawowych i rozszerzonych oraz bez określenia zakresu. Do celów badawczych wybrano tylko tradycyjne podręczniki papierowe ${ }^{3}$.

Należy zaznaczyć, że podręcznik szkolny do historii realizuje swoją podstawową funkcję naukowo-informacyjną poprzez dostarczanie uczniom aktualnej wiedzy o procesie dziejowym w dostosowanej do możliwości intelektualnych i percepcyjnych odbiorcy ( $\mathrm{tj}$. ucznia) formie. Zakres tematyczny wiedzy określa podstawa programowa, która najczęściej poprzez rozwiniętą formułę konkretnego programu nauczania stanowi dla autora konstrukcyjny szkielet podręcznika. Przegląd wybranych podręczników pozwolił na wyszczególnienie czterech zagadnień mieszczących się w interesującym nas wątku tematycznym dotyczącym epidemii: epidemie

2 Na temat roli podręcznika szkolnego do historii w procesie kształcenia zob. Adam Suchoński, „Podręcznik. Funkcje podręcznika”, w Jerzy Maternicki, Czesław Majorek, Adam Suchoński, Dydaktyka historii (Warszawa: Wydawnictwo Naukowe PWN, 1994), 344-345; Alojzy Zielecki, Rola i funkcje podręcznika historii (Rzeszów: Wydawnictwo WSP Rzeszów, 1984); Maria Bieniek, „Podręcznik szkolny historii”, w Współczesna dydaktyka historii. Zarys encyklopedyczny. Dla nauczycieli i studentów, red. Jerzy Maternicki (Warszawa: Wydawnictwo Juka, 2004), 266-269.

3 Badanie przeprowadzone na próbie 44 podręczników miało charakter jakościowy. Przy analizie podręczników posłużono się metodą analizy źródeł i metodą porównawczą. W badaniu wykorzystano podręczniki wydane przez następujące wydawnictwa: Wydawnictwa Szkolne i Pedagogiczne (17), Nowa Era (6), Operon (5), PWN (6), Znak (3), Polskie Przedsiębiorstwo Wydawnictw Kartograficznych (2), Miscellanea (2), SOP (1), Gdańskie Wydawnictwo Oświatowe (1), Wiking (1). Z tego osiem podręczników zostało wydanych w latach 1989-2000, a 12 po $2011 \mathrm{r}$. Ponad połowa analizowanych podręczników (24) została wydana w latach 2001-2010. Zdaniem piszącego był to najbardziej twórczy okres po 1989 r., jeśli chodzi o edycje podręczników szkolnych do historii w zakresie szkoły średniej, związany z realizacją reformy oświaty z 1999 r. (tzw. reformy Handkego). 
w okresie antyku, tzw. czarna śmierć w latach 1346-1353, epidemie na obszarach Nowego Świata w okresie odkryć geograficznych oraz epidemia grypy, tzw. hiszpanki. W przeprowadzonej analizie nie uwzględniono rozproszonych na kartach podręczników informacji dotyczących na przykład walki człowieka z chorobami zakaźnymi w XVIII czy XIX w., co wymagałoby znacznego rozszerzenia zakresu kwerendy.

\section{Epidemie w okresie starożytności}

Epidemie w okresie antyku tylko w niewielkim stopniu zostały zauważone przez autorów analizowanych podręczników. Incydentalnie pojawiają się informacje dotyczące epidemii, która wybuchła w Atenach w okresie wojny peloponeskiej (429-426 p.n.e.) i przyczyniła się do dużej śmiertelności mieszkańców miasta, w tym do śmierci samego Peryklesa ${ }^{4}$. O epidemiach w okresie rzymskim uczniowie dowiadują się w kontekście analizy tzw. kryzysu III w. bądź też generalnie przy omówieniu przyczyn upadku cesarstwa na Zachodzie. Ogólne informacje na temat konsekwencji epidemii z połowy III w. znajdziemy w podręczniku wydawnictwa Operon z 2019 r., gdzie autorzy stwierdzili, że „nasilające się w tym okresie epidemie groźnych chorób zaowocowały spadkiem zaludnienia niektórych obszarów oraz zahamowaniem rozwoju miast i zmniejszeniem ich znaczenia"'. Do masowych zachorowań w tym czasie najszerzej nawiązał w swoim podręczniku z $1999 \mathrm{r}$. Adam Ziółkowski, który w wyjaśnianiu genezy wspomnianego kryzysu cesarstwa podkreślił znaczenie kolejnych fal epidemii (tzw. zarazy Antoninów i tzw. zarazy Cypriana) ${ }^{6} \mathrm{w}$ osłabieniu struktur militarnych państwa rzymskiego. Jak zaznaczył, „w 166 roku legiony wracające ze zwycięskiej wojny z Partami zawlokły do Imperium zarazę, która poczyniła szczególne spustoszenia w prowincjach granicznych, gdzie stacjonowało wojsko". W połowie III w., a konkretnie w 249 r., sytuacja

4 Jan Iluk, Anna Paner, Historia. Podręcznik dla szkól średnich. Tom I Starożytność (Koszalin: Wydawnictwo Miscellanea, 1996), 113; Andrzej Wypustek, Marek L. Wójcik, Ze świata do Polski przez Europę. Starożytność. Średniowiecze. Podręcznik historii dla klasy 1 liceów ogólnokształcących, liceów profilowanych oraz techników (Wrocław-Warszawa: Polskie Przedsiębiorstwo Wydawnictw Kartograficznych, 2002), 94; Anna Krzeszowska, Andrzej Wypustek, Historia Starożytność. Podręcznik dla klasy 1 liceum ogólnokształcącego, liceum profilowanego i technikum. Zakres podstawowy i rozszerzony (Wrocław: Wydawnictwo Edukacyjne Wiking, 2002), 90; Marek Węcowski, Piotr Węcowski, Jarosław Czubaty, Historia. Podręcznik. Klasa 1. Szkoły ponadgimnazjalne. Zakres podstawowy (Warszawa: Wydawnictwo Szkolne PWN, 2007), 59; Ryszard Kulesza, Krzysztof Kowalewski, Zrozumieć przeszłość 1. Podręcznik do historii dla liceum ogólnokształcącego i technikum. Zakres rozszerzony (Warszawa: Wydawnictwo Nowa Era, 2019), 113.

Mirosław Ustrzycki, Janusz Ustrzycki, Historia 1. Starożytność. Podręcznik dla szkół ponadpodstawowych. Zakres rozszerzony (Gdynia: Wydawnictwo Operon, 2019), 220.

6 Zob. Olga Błyskal, „Dżuma w Imperium Rzymski. Medyczne studium przypadku”, w Epidemie w dziejach Europy, 16-30. 
uległa znacznemu pogorszeniu, gdyż „do ucisku podatkowego, rosnącej inflacji, wojen domowych i najazdów doszła najstraszniejsza klęska - zaraza, która tym razem ogarnęła całe Imperium i pochłonęła nieporównanie więcej ofiar. Trwała ok. 20 lat i była główną przyczyną całkowitego załamania się rzymskiego systemu obronnego"7. Warto zaznaczyć, że w następnym swoim podręczniku z 2002 r. A. Ziółkowski mocno podkreślił znaczenie wielkich epidemii w wymiarze rozwoju ekonomicznego i demograficznego imperium rzymskiego. Wraz z intensyfikacją wymiany handlowej i kontaktów ze światem zewnętrznym od II w. n.e. region śródziemnomorski zaczęły nawiedzać rozprzestrzeniające się ze Wschodu epidemie, które w ostateczności przyniosły regres cywilizacyjny, przezwyciężony, jak zaznaczył Autor, na niektórych obszarach tego regionu dopiero w XIX w., a nawet XX w. ${ }^{8}$ W tym samym podręczniku Autor nawiązał także do następstw pandemii z czasów justyniańskich (tzw. dżumy Justyniana). Według niego była to „najstraszniejsza zaraza, jaka kiedykolwiek dotknęła Europę i świat śródziemnomorski, trwająca z nawrotami ok. 60 lat (542 - ok. 600)"'. Zahamowała ona sukcesy polityczno-wojskowe cesarza, osłabiła cesarstwo i w konsekwencji wyludnienia przypieczętowała upadek miast, na których opierała się cywilizacja klasyczna.

Podsumowując, epidemie w okresie antyku w zdecydowanej większości zanalizowanych podręczników nie zostały uwzględnione. Na tym tle wyróżniają się podręczniki Adama Ziółkowskiego, który konsekwencje kolejnych fal epidemii w II i III w. powiązał z kryzysem państwowości rzymskiej oraz uwypuklił znaczenie epidemii dżumy z okresu panowania Justyniana dla końca cywilizacji antycznej ${ }^{10}$.

7 Adam Ziółkowski, Dzieje starożytne 1. Podręcznik dla klas pierwszych szkól średnich (Warszawa: Wydawnictwa Szkolne i Pedagogiczne, 1999), 292, 294; tak silne położenie nacisku na znaczenie tej epidemii kontrastuje z ujęciem kryzysu III w. w znanym podręczniku Ewy Wipszyckiej (Cywilizacja starożytna. Podręcznik dla szkół średnich. Wersja rozszerzona [Warszawa: Wydawnictwo Szkolne PWN, 2000]). Autorka szczegółowo omawia wspomniany kryzys (s. 99-103), ale bez odniesień do epidemii rozwijającej się od 249 r. Zob. także Ewa Wipszycka, Historia dla Maturzysty. Starożytność. Podręcznik. Szkoły ponadgimnazjalne. Zakres rozszerzony (Warszawa: Wydawnictwo Szkolne PWN, 2004), 170-172 (podobnie). Tak samo w podręczniku Krzysztofa Polka i Marka Wilczyńskiego, Historia. Ludzie i epoki. Klasa 1. Podręcznik do historii obejmujacy kształcenie $w$ zakresie podstawowym w liceum ogólnokształcącym, liceum profilowanym i technikum oraz kształcenie $w$ zakresie rozszerzonym $w$ liceum ogólnokształcącym i liceum profilowanym (Kraków: Wydawnictwo Znak, 2003), 166.

8 Adam Ziółkowski, Człowiek i historia. Część 1. Czasy starożytne. Kształcenie w zakresie rozszerzonym. Podręcznik dla liceum ogólnokształcącego (Warszawa: Wydawnictwa Szkolne i Pedagogiczne, 2002), 73; zaraza justyniańska zob. Teresa Wolińska, „Pierwsza europejska pandemia”, w Epidemie w dziejach Europy, 31-60.

9 Ziółkowski, Człowiek i historia, 60, 128; krótka wzmianka o epidemii z 542 r. w Kulesza, Kowalewski, Zrozumieć przeszłość 1, 239.

10 O wpływie epidemii na wyludnienie niektórych (bez sprecyzowania) obszarów europejskich na przełomie epoki starożytnej i średniowiecza (VI-VII w.) zob. Halina Manikowska, Historia dla maturzysty. Średniowiecze. Szkoły ponadgimnazjalne. Zakres rozszerzony (Warszawa: Wydawnictwo Szkolne PWN, 2007), 159. 


\section{Czarna śmierć w latach 1346-1353 ${ }^{11}$}

Najpełniejszy obraz charakteru i znaczenia wielkiej epidemii dla życia społecznego otrzymali uczniowie w odniesieniu do tzw. czarnej śmierci z połowy XIV w., czyli wielkiej fali zachorowań na dżumę wywołaną przez bakterię Yersinia pestis. Zjawisko to doczekało się wielu różnorodnych ujęć dydaktyczno-historycznych zamieszczonych w licznych cyklach podręcznikowych po $1989 \mathrm{r}$. W analizowanych podręcznikach epidemia ta prezentowana była w kontekście kryzysu społeczno-gospodarczego, który pojawił się w najlepiej rozwiniętych państwach europejskich w początkach XIV w. Ten model prezentacji zjawiska czarnej śmierci charakterystyczny był dla podręczników, które zachowywały układ liniowo-chronologicznej narracji ${ }^{12}$. W podręcznikach zbudowanych w oparciu o problemową charakterystykę epoki wspomniana epidemia dżumy prezentowana była w kontekście przemian demograficznych lub gospodarczo-społecznych $\mathrm{w}$ średniowieczu ${ }^{13}$.

W analizowanych podręcznikach autorzy obrazowo przedstawiali genezę omawianego zjawiska, rozbudowując warstwę wyjaśniającą tekstu autorskiego. Uczniowie otrzymywali informacje, że w początkach XIV w. „rolnicy porzucali wyjałowioną glebę, spadały plony, pojawiły się nieurodzaje a wraz z nimi

11 Na temat tej epidemii istnieje olbrzymia literatura, np. Katharine Park, Black Death, The Cambridge World History of Human Disease, ed. Kenneth F. Kiple (New York: Cambridge University Press, 1993), 612-616; John. P. Byrne, Encyclopedia of the Black Death (Santa Barbara: ABC-Clio, 2012), 42-52; Ole Benedictow, The Black Death, 1346-1353, The Complete History (Rochester: Boydel Press, 2004), passim.

12 Halina Manikowska, Julia Tazbirowa, Historia. Średniowiecze. Podręcznik dla szkól średnich klasy I liceum ogólnokształcącego, technikum i liceum zawodowego (Warszawa: Wydawnictwa Szkolne i Pedagogiczne, 1995), 152-153; Bogumiła Burda, Bohdan Halczak, Roman Józefiak, Małgorzata Szymczak, Historia 1. Średniowiecze. Część 2. Zakres rozszerzony. Podręcznik dla liceum ogólnoksztatcącego (Gdynia: Wydawnictwo Operon, 2002), 178-179; Michał Norbert Faszcza, Radosław Lolo, Krzysztof Wiśniewski, Historia 1. Podręcznik. Liceum i technikum. Zakres podstawowy (Warszawa: Wydawnictwa Szkolne i Pedagogiczne, 2019), 222-223; Jolanta Choińska-Mika, Włodzimierz Lengauer, Michał Tymowski, Katarzyna Zielińska, Historia 1. Podręcznik. Liceum i technikum. Zakres rozszerzony (Warszawa: Wydawnictwa Szkolne i Pedagogiczne, 2019), 394-395; Janusz Ustrzycki, Mirosław Ustrzycki, Historia 2. Średniowiecze. Podręcznik dla szkół ponadpodstawowych. Zakres rozszerzony (Gdynia: Wydawnictwo Operon, 2019), 240-242; Węcowski, Węcowski, Czubaty, Historia. Podręcznik. Klasa 1, 220-221; tylko incydentalne zob. Anna Paner, Jan Iluk, Historia. Podręcznik dla szkół średnich. Część II. Średniowiecze (Koszalin: Wydawnictwo Miscellanea, 1997), 420, 429; Polek, Wilczyński, Historia. Ludzie i epoki. Klasa 1, 327.

13 Michał Tymowski, Człowiek i historia. Część 2. Czasy średniowiecza. Kształcenie w zakresie rozszerzonym. Podręcznik dla liceum ogólnokształcącego (Warszawa: Wydawnictwa Szkolne i Pedagogiczne, 2002), 57, 72; Manikowska, Historia dla maturzysty. Średniowiecze, 190-191; Ewa Wipszycka, Halina Manikowska, Adam Manikowski, Włodzimierz Mędrzecki, Historia dla każdego. Podręcznik, tom 1. Do rewolucji francuskiej. Szkoły ponadgimnazjalne. Zakres podstawowy (Warszawa: Wydawnictwo Szkolne PWN, 2002), 165-166. 
głody. Na niedożywioną ludność uderzyły zarazy ${ }^{14}$. Pierwszymi niekorzystnymi zjawiskami, odczuwalnymi już w pierwszych dziesięcioleciach XIV stulecia były: ochłodzenie klimatu, wyjałowienie gleb i spadek plonów. W niedożywioną, osłabioną ludność uderzyło kilka fal epidemii" ${ }^{15}$. Niekiedy autorzy starali się jeszcze bardziej scharakteryzować tło zbliżającego się kataklizmu: „niski poziom nawożenia sprawiał, że ziemia była stopniowo wyjaławiana. Na przełomie XIII i XIV wieku nastąpiło ochłodzenie klimatu i znaczny wzrost opadów. Wszystkie te czynniki spowodowały załamanie się rolnictwa zachodnioeuropejskiego, w wielu rejonach pojawiła się głód"16. W dalszej kolejności pojawił się kryzys finansowy ze wszystkimi jego negatywnymi skutkami, a następnie ciąg niekorzystnych zjawisk (niedożywienie, spadek przyrostu naturalnego, wzrost śmiertelności), tworzących dobrą podbudowę do uaktywnienia się czynnika biologicznego, którym była pałeczka dżumy.

Sam przebieg epidemii autorzy analizowanych tekstów przedstawiają bardzo podobnie, a więc zamieszczając podstawowe informacje dotyczące samej choroby, chronologii zdarzeń, kierunków rozprzestrzeniania się, zasięgu terytorialnego ${ }^{17}$. Spotykamy także bardziej szczegółowe opisy jej przebiegu, jak w podręczniku Jana Wróbla z 2002 r., który wykorzystał fragmenty XIV-wiecznego walijskiego poematu sugestywnie obrazującego fizyczne cierpienia chorego człowieka. Opatrzył on to komentarzem: „opisał precyzyjnie podstawowe objawy dżumy dymieniczej, siny guz w pachwinie lub pod pachą. Medycy pozostawali właściwie bezradni. Niektórzy przecinali te guzy, co przynosiło ulgę w cierpieniach, nie ratowało jednak życia. Żeby je uratować, był tylko jeden sposób: w porę uciec w bezpieczne miejsce i zerwać kontakty ze światem zewnętrznym (ewentualnie zamknąć odpowiednio wcześniej granice miasta czy hrabstwa i starać się przetrwać). Albo mieć szczęście”"18.

14 Tadeusz Cegielski, Włodzimierz Lengauer, Michał Tymowski, Ludzie, społeczeństwa, cywilizacje. Historia. Starożytność i średniowiecze. Część I. Podręcznik do historii dla liceum ogólnokształcacego, liceum profilowanego i technikum. Kształcenie w zakresie podstawowym (Warszawa: Wydawnictwa Szkolne i Pedagogiczne, 2002), 309.

15 Choińska-Mika, Lengauer, Tymowski, Zielińska, Historia 1. Podręcznik, 334.

16 Zofia T. Kozłowska, Irena Unger, Piotr Unger, Stanisław Zając, Poznajemy przeszłość do końca XVII wieku. Podręcznik dla liceum ogólnokształcącego. Zakres rozszerzony (Toruń: SOP Oświatowiec, 2005), 199.

17 W podręczniku Burda, Halczak, Józefiak, Szymczak, Historia 1. Średniowiecze. Część 2, 178, wyjaśniono osobno samo pojęcie dżumy - „bardzo zaraźliwa, gwałtowna, groźna dla życia epidemiczna choroba, wywoływana przez pałeczkę dżumy; przenoszona na ludzi ze zwierząt (głownie szczur) przez pchły”; w podręczniku Wipszycka, Manikowska, Manikowski, Mędrzecki, Historia dla każdego. Podręcznik, tom 1, 166, zaznaczono, że „ostatnio para badaczy angielskich zasugerowała, biorąc pod uwagę szybkość rozprzestrzeniania się epidemii i jej rozmiary, że przyczyną choroby mógł być wirus podobny do Eboli”.

18 Jan Wróbel, Odnaleźć przeszłość. Część 1, Od starożytności do 1815 roku. Podręcznik. Ksztatcenie w zakresie podstawowym (Warszawa: Wydawnictwa Szkolne i Pedagogiczne, 2002), 194. 
W podręcznikach podkreślano z jednej strony bezradność ówczesnych społeczeństw wobec rozprzestrzeniającej się epidemii, z drugiej - wskazywano na podejmowane próby jej powstrzymania. Tak dramatyczne doświadczenie skłaniało ludzi do wypracowania metod radzenia sobie z zagrożeniem epidemicznym. Jak podkreśliła w swoim podręczniku z 2007 r. Halina Manikowska, „Nauczono się lepiej magazynować żywność i organizować jej dostawy. Kartki na chleb (dla 90 tyś. ludzi) w prowadzono w latach czterdziestych XIV wieku we Florencji, by zapobiec w czasie wielkiego głodu masowej śmierci mieszkańców. Zaczęto stosować kordony sanitarne, by nie dopuszczać do rozprzestrzenia się epidemii. Zaraza zresztą przyczyniła się do rozwoju medycyny"19.

W podręcznikach nie mogło zabraknąć treści odnoszących się do konsekwencji demograficznych, społecznych, gospodarczych i kulturowych epidemii czarnej śmierci. W analizowanych tekstach bardzo mocno podkreślono wielokierunkowość i długofalowość skutków epidemii. Obrazowo przedstawił to w swoim podręczniku Michał Tymowski: „Ludność Europy, licząca przed tą klęską ok. $73 \mathrm{mln}$, spadła do ok. $45 \mathrm{mln}$ w roku 1440. Zaraza szczególnie wyniszczyła wielkie skupiska ludzkie, w tym najlepiej rozwinięte miasta i ich najbliższe wiejskie zaplecze. Gwałtowny spadek liczby ludności spowodował dalsze obniżenie się produkcji wiejskiej i miejskiej oraz zmniejszenie się dochodów feudałów. Wywołało to napięcia społeczne i walkę o malejące dochody między różnymi grupami społecznymi. Malały również dochody skarbów królestw, a próby zapobieżenia temu przez władców przynosiły nowe napięcia i konflikty"20. Straty ludnościowe pokazywano nie tylko w ujęciu ogólnoeuropejskim czy krajowym, ale i w mikroskali. Przykładem może być podręcznik Janusza i Mirosława Ustrzyckich z 2019 r., gdzie zamieszczono szczegółowe dane dotyczące śmiertelności mieszkańców wioski Givry w Burgundii i mieszkańców biskupich dóbr Tauton w Anglii w latach 1346-134921. Zjawisko czarnej śmierci wyzwoliło także silną falę wystąpień antysemickich, co zostało uwypuklone w omawianych podręcznikach. Jak zaznaczono w jednym z nich, „bezsilni ludzie, nierozumiejący przyczyn epidemii, szukali winnych w mniejszościach etnicznych (Żydach czy Romach), w wyniku czego dochodziło do pogromów”22.

19 Manikowska, Historia dla maturzysty. Średniowiecze, 190; skutki czarnej śmierci zob. także: Węcowski, Węcowski, Czubaty, Historia. Podręcznik. Klasa 1, 220-221; Jolanta Choińska-Mika, Włodzimierz Lengauer, Michał Tymowski, Katarzyna Zielińska, Historia. Poznać, zrozumieć. Podręcznik dla liceum i technikum. Część 1. Zakres podstawowy (Warszawa: Wydawnictwa Szkolne i Pedagogiczne, 2007), 283-284; Kozłowska, Unger, Unger, Zając, Poznajemy przeszłość do końca XVII wieku, 199-201; Tomasz Jurek, Dzieje średniowieczne. Podręcznik dla kasy I szkół średnich (Warszawa: Wydawnictwa Szkolne i Pedagogiczne, 1999), 257-259; Wróbel, Odnaleźć przeszłość, 195-196; Kulesza, Kowalewski, Zrozumieć przeszłość 1, 517.

20 Tymowski, Człowiek i historia. Część 2, 72.

21 Ustrzycki, Ustrzycki, Historia 2. Średniowiecze, 242.

22 Faszcza, Lolo, Wiśniewski, Historia 1. Podręcznik, 224; na temat rozruchów antyżydowskich zob. także: Ustrzycki, Ustrzycki, Historia 2. Średniowiecze, 244; Karol Kłodziński, Krzysztof 
Warto zauważyć, że autorzy analizowanych tekstów byli zgodni co do pozytywnej sytuacji krajów Europy Środkowej, w tym ziem polskich, które szczęśliwie nie zostały mocno doświadczone tą chorobą ${ }^{23}$.

$\mathrm{W}$ analizowanych materiałach spotykamy różne elementy tzw. obudowy dydaktycznej, uzupełniające warstwę informacyjną podręcznika i zarazem będące przedłużeniem narracji tekstowej odnoszącej się do czarnej śmierci. Wskazać w tym miejscu możemy teksty źródłowe z powtarzającym się fragmentem Dekameronu Giovanniego Boccaccia, opisującym skutki czarnej śmierci w Toskanii24. Przykładem może być także wykorzystana ikonografia (tzw. ikonika podręcznikowa), która odwołuje się do charakterystycznego dla późnego średniowiecza motywu śmierci. W omawianych podręcznikach znajdziemy liczne tego przykłady ilustrujące zarazem tekst autorski ${ }^{25}$. W podręczniku Tadeusza Cegielskiego, Włodzimierza Lengauera i Michał Tymowskiego z 2002 r. miniatura z początku XV w. przedstawiająca procesję błagalną przeciw zarazie stała się podstawą samodzielnego i bardzo rozbudowanego ćwiczenia interpretacyjnego, składającego się z poleceń: „Opisz osoby biorące udział w procesji. Czego oczekiwali po niej uczestnicy i obserwatorzy? Jakie wydarzenie zostało umieszczone na pierwszym planie miniatury i przyciąga uwagę? Czy wielkie zgromadzenia ludzi przeszkadzały czy sprzyjały szerzeniu się zarazy? Czy śmierć na zarazę $\mathrm{w}$ trakcie procesji umacniała czy osłabiała wiarę ludzi w pomocną funkcję obrzędów religijnych? Połącz wymowę tej sceny z wiadomością o upadku autorytetów w czasie kryzysu" ${ }^{26}$. Narrację tekstową i ikoniczną w analizowanych podręcznikach dopełniają środki kartograficzne i symboliczne. Szczególnie te drugie,

Krzemiński, Poznać przeszłość. Europa i świat. Podręcznik do historii i społeczeństwa dla liceum ogólnokształcacego i technikum (Warszawa: Wydawnictwo Nowa Era, 2015), 56.

23 Wróbel, Odnaleźć przeszłość, 194; Kozłowska, Unger, Unger, Zając, Poznajemy przeszłość do końca XVII wieku, 200; Choińska-Mika, Lengauer, Tymowski, Zielińska, Historia. Poznać, zrozumieć, 284; Ustrzycki, Ustrzycki, Historia 2. Średniowiecze, 241 (jak stwierdzili autorzy, co jest rzadkie w przypadku podręczników szkolnych - „Mimo wielu stawianych hipotez nie znaleziono dotąd przekonywującego wyjaśnienia tego faktu”); epidemia czarnej śmierci na ziemiach polskich zob. Agata Chilińska, Urszula Zawadzka, Arkadiusz Sołtysiak, „Pandemia dżumy w latach 1348-1379 na terenach Królestwa Polskiego. Model epidemiologiczny i źródła historyczne”, w Epidemie, klęski, wojny, red. Wojciech Dzieduszycki, Jacek Wrzesiński, Funeralia Lednickie - Spotkanie, t. 10 (Poznań: Stowarzyszenie Naukowe Archeologów Polskich, 2008), 165-174.

24 Ustrzycki, Ustrzycki, Historia 2. Średniowiecze, 244; Choińska-Mika, Lengauer, Tymowski, Zielińska, Historia. Poznać, zrozumieć, 290; Kozłowska, Unger, Unger, Zając, Poznajemy przeszłość do końca XVII wieku, 199 (w tym samym podręczniku na s. 200 wykorzystano także fragment Roczników Jana Długosza odnoszący się do opisu zarazy z 1348 r.).

25 Manikowska, Tazbirowa, Historia. Średniowiecze, 154; Węcowski, Węcowski, Czubaty, Historia. Podręcznik. Klasa 1, 220; Ustrzycki, Ustrzycki, Historia 2. Średniowiecze, 242; Tomasz Jurek, Dzieje średniowieczne, 258, 340; Wróbel, Odnaleźć przeszłość, 195.

${ }_{26}$ Cegielski, Lengauer, Tymowski, Ludzie, społeczeństwa, cywilizacje, 311; to samo przedstawienie, ale już z interpretacją autorską, zob. Choińska-Mika, Lengauer, Tymowski, Zielińska, Historia. Poznać, zrozumieć, 283. 
w postaci tabel i diagramów, dają możliwość pokazania dynamiki zmian demograficznych wywołanych epidemią ${ }^{27}$.

Zaprezentowany powyżej obraz wielkiej epidemii dżumy z XIV w. zawarty na kartach analizowanych podręczników pokazuje, że zjawisko to zostało rzetelnie przepracowane przez autorów w komunikatywną dla odbiorcy szkolnego narrację. Autorzy, oprócz swojego własnego tekstu, wykorzystali także dodatkowe elementy przekazu, takie jak mapy czy ilustracje. Taka konstrukcja obrazu czarnej śmierci pozwala dostrzec podstawowe związki przyczynowo-skutkowe i zrozumieć istotę tego dramatycznego zjawiska, integralnie związanego z dziejami naszego kontynentu.

\section{Epidemie w Nowym Świecie w okresie wielkich odkryć geograficznych}

W analizowanych podręcznikach nie mogło zabraknąć treści odnoszących się do konsekwencji tragicznego zderzenia cywilizacyjnego, które miało miejsc w Nowym Świecie po 1492 r. Omawiane prace przynoszą najczęściej podstawowe informacje dotyczące masowych zachorowań ludności autochtonicznej na choroby zakaźne pochodzące z Europy, takie jak ospa, dżuma, tyfus czy cholera, chociaż sprowadzają się tylko do zasygnalizowania najistotniejszych faktów ${ }^{28}$. Duża śmiertelność Indian w wyniku wspomnianych chorób zestawiana

27 Na przykład: Węcowski, Węcowski, Czubaty, Historia. Podręcznik. Klasa 1, 220 (tabela szacunkowego zestawienia ludności Europy zachodniej w latach 1000-1440); Cegielski, Lengauer, Tymowski, Ludzie, społeczeństwa, cywilizacje Ludzie, społeczeństwa, cywilizacje, 310 (diagram obrazujący piramidę ludności w Bolonii w 1395 r. oraz wiek ludności miejskie we Florencji w 1371 r.); Michał Tymowski, Człowiek i historia. Część 2, 57 (tabela zmian demograficznych w wybranych państwach europejskich w średniowieczu); Kulesza, Kowalewski, Zrozumieć przeszłość 1, 517 (mapa Europy obrazująca rozprzestrzeniane się epidemii w XIV w.), Halina Manikowska, Julia Tazbirowa, Historia. Średniowiecze, 153 (mapa zachodniej Europy wraz z zasięgiem epidemii).

28 Mikołaj Gładysz, Historia I. Podręcznik dla klasy pierwszej liceum i technikum. Zakres podstawowy i rozszerzony. Cz. 2, Od średniowiecza do nowożytności (Gdańsk: Gdańskie Wydawnictwo Oświatowe, 2002), 143; Adam Kucharski, Aneta Niewęgłowska. Poznać Przeszłość 2. Podręcznik do historii dla liceum ogólnokształcacego i technikum. Zakres podstawowy (Warszawa: Wydawnictwo Nowa Era, 2020), 232 (w kontekście plemion północnoamerykańskich); Bogumiła Burda, Bohdan Halczak, Roman Józefiak, Anna Roszak, Małgorzata Szymczak, Historia 2. Czasy nowożytne. Zakres rozszerzony. Podręcznik dla liceum ogólnokształcącego (Gdynia: Wydawnictwo Operon, 2003), 53; Krystyna Zielińska, Zofia Kozłowska, Historia 2. Dzieje Nowożytne 1492-1815. Podręcznik dla klasy II liceum ogólnokształcącego (Warszawa: Wydawnictwa Szkolne i Pedagogiczne, 1995), 18; Tadeusz Cegielski, Mirella Krukowska, Człowiek i historia 3. Czasy nowożytne do 1815 roku. Kształcenie w zakresie rozszerzonym. Podręcznik dla liceum ogólnokształcącego (Warszawa: Wydawnictwa Szkolne i Pedagogiczne, 2002), 420-421; Marek L. Wójcik, Agnieszka Knychalska, Historia 2. Czasy nowożytne, Ze świata do Polski przez Europę. Cz. 1, Podręcznik historii dla klasy 1 liceów ogólnokształcących, liceów profilowanych oraz techników (Wrocław-Warszawa: Polskie Przedsiębiorstwo Wydawnictw 
jest $\mathrm{z}$ innymi czynnikami, które spowodowały olbrzymie załamanie populacji indiańskiej w XVI w., takimi jak wojny, system pracy przymusowej (enconmienda), utrata terenów rolniczych, głód i alkoholizm. Jako przykład bardziej rozbudowanego ujęcia, choć nie do końca precyzyjnego, możemy podać podręcznik Karola Kłodzińskiego i Tomasza Krzemińskiego z 2015 r., w którym autorzy informują czytelników o epidemii ospy wietrznej (?), która zdziesiątkowała obrońców Tenochtitlanu w sierpniu 1521 r. oraz ludność inkaską w 1533 r. Wspomniani autorzy w podrozdziale zatytułowanym Skutki ekologiczne i kulturowe wielkich odkryć tak podsumowali konsekwencje demograficzne tych wydarzeń: „Ponadto koloniści zawlekli do Ameryki nieznane tam choroby zakaźne. Układ odpornościowy Indian nie był dostosowany do zwalczania schorzeń, które Europejczycy przechodzili dość łagodnie (ospa wietrzna, odra, grypa itp.). Dla rdzennej ludności Ameryki okazały się one śmiertelne. Szacuje się, ze w XVI i XVII wieku zachorowało i umarło ponad 3/4 populacji półkuli zachodniej. Była to najprawdopodobniej największa katastrofa demograficzna w historii ludzkości [...]"29. Dla wzmocnienia przekazu wykorzystano w tym podręczniku rycinę z Kodeksu Florentyńskiego (Codex Florentino), wykonaną przez azteckich rysowników, przedstawiającą fazy przebiegu, jak podpisano, ospy wietrznej ${ }^{30}$. Z kolei w najnowszym podręczniku Mirosława i Janusza Ustrzyckich z 2020 r. Autorzy krótko informują uczniów o wyniszczających Indian epidemiach przywiezionych przez Europejczyków, ale dodatkowo obudowują tekst autorski ćwiczeniem zaopatrzonym w wykres pokazujący zmiany liczby ludności Meksyku w latach 1519-1605 i stawiają uczniom konkretne polecenie: „Policz, ile razy zmniejszyła się liczba ludności Meksyku w czasie przedstawionym na wykresie. Wyjaśnij, jakie były przyczyny tego zjawiska" ${ }^{\text {"1 }}$. Ten sam wykres, ale już bez obudowy ćwiczeniowej wykorzystał w swoim podręczniku Piotr Klint ${ }^{32}$. W tekście autorskim podkreślił znaczenie takich chorób, jak dżuma, żółta febra, cholera, tyfus i ospa prawdziwa, w stratach ludnościowych (80-90\%) plemion indiańskich w pierwszym półwieczu kolonizacji.

Wielkie epidemie, które przetoczyły się przez obie Ameryki po 1492 r., w analizowanych podręcznikach zaprezentowane zostały jako część konsekwencji wielkich

Kartograficznych, 2003), 41; Bożena Popiołek, Historia. Ludzie i epoki, klasa 2. Podręcznik do historii obejmujący kształcenie w zakresie podstawowym w liceum ogólnokształcacym, liceum profilowanym i technikum oraz kształcenie $w$ zakresie rozszerzonym $w$ liceum ogólnokształcacym i liceum profilowanym (Kraków: Wydawnictwo Znak, 2003), 28; Halina Manikowska, Julia Tazbirowa, Historia. Sredniowiecze, 219.

29 Kłodziński, Krzemiński, Poznać przeszłość. Europa i świat, 81, zob. także 28, 76, 77.

30 Tę samą ilustracje znajdujemy w Kucharski, Niewęgłowska, Poznać Przeszłość 2, 20, z informacją, że na czarną ospę zmarło ponad 70\% Azteków i 90\% Inków.

31 Mirosław Ustrzycki, Janusz Ustrzycki, Historia 2. Nowożytność do końca XVII w. Podręcznik dla szkół ponadpodstawowych. Część 1, Zakres rozszerzony (Gdynia: Wydawnictwo Operon, 2020), 56-57 (w wersji podstawowej tego podręcznika s. 41).

32 Paweł Klint, Zrozumieć przeszłość 2. Podręcznik do historii dla liceum ogólnokształcacego i technikum. Zakres rozszerzony (Warszawa: Wydawnictwo Nowa Era, 2020), 31-32. 
odkryć geograficznych, bez wchodzenia w szczegóły, ale z elementarnym poziomem wyjaśnienia zjawiska. Mocno podkreślono bezprecedensową w dziejach skalę załamania demograficznego całej populacji rdzennej ludności amerykańskiej. Niestety w tym obrazie nie zabrakło nieścisłości i uproszczeń. Przykładem jest błędna identyfikacja ospy jako wietrznej (varicella), a nie prawdziwej (variola vera/negra) wyniszczającej Azteków i Inków w latach dwudziestych i trzydziestych XVI w. we wspomnianym już podręczniku K. Kłodzińskiego i K. Krzemińskiego. Z kolei przypisywanie wyłącznie ospie prawdziwej i innym chorobom ze Starego Świata decydującej roli w wysokiej śmiertelności ludności autochtonicznej jest współcześnie kwestionowane i stanowi przedmiot dyskusji naukowej ${ }^{33}$. Osobną kwestią są stwierdzenia Autorów odnoszące się do ilościowych lub procentowych strat ludności indiańskiej w wyniku masowych zachorowań w XVI w. Mają one charakter przybliżony, co nie jest przez Autorów zaznaczone.

\section{Pandemia grypy, tzw. hiszpanki ${ }^{34}$}

Najbliższe nam czasowo doświadczenie społeczne wielkiej epidemii (pandemii) dotyczyło tzw. hiszpanki, czyli masowych zachorować na grypę tuż po zakończeniu I wojny światowej (1918-1920). Informacje na ten temat pojawiają się w analizowanym materiale w kontekście konsekwencji demograficznych i społeczno-ekonomicznych Wielkiej Wojny ${ }^{35}$. Podobnie jak w przypadku wyżej

33 Masowe zachorowania ludności rodzimej w Meksyku w XVI w. wiązane są nie tylko z „europejskimi” chorobami przyniesionym przez Hiszpanów, ale i koincydencją takich czynników, jak: susze, głód, eksploatacja ekonomiczna, które w połowie wieku dały impuls do rozwoju epidemii prawdopodobnie endemicznej choroby określanej w języku nahuatl terminem cocoliztli. Identyfikacja tej choroby jest przedmiotem badań (wirusowa gorączka krwotoczna?, salmonelloza?), zob. Rodolf Acun-Soto, David W. Stahle, Malcolm K. Cleaveland, Matthew D. Therrell, „Megadrought and Megadeath in $16^{\text {th }}$ Century Mexico", Emerging Infectious Diseases 8 (2002): 360-362; Paul Chrystal, The History of the World in 100 Pandemics, Plagues and Epidemics (Barnsley: Pen \& Sword Books, 2021), 133-137.

34 Na temat hiszpanki np. John. M. Barry, The Great Influenza: The Epic Story of the Greatest Plague in History (New York: Viking Books, 2004); Niall Johnson, Britain and the 1918-19 Influenza Pandemic: A Dark Epilogue (London: Routledge, 2006).

35 Grażyna Szelągowska, Ludzie, społeczeństwa, cywilizacje. Historia XIX i XX w. Część III. Podręcznik do historii dla liceum ogólnokształcacego, liceum profilowanego i technikum (Warszawa: Wydawnictwa Szkolne i Pedagogiczne, 2003), 172; Grzegorz Szymanowski, Piotr Trojański, Historia. Ludzie i epoki, klasa 3. Podręcznik do historii obejmujący kształcenie w zakresie podstawowym $w$ liceum ogólnokształcacym, liceum profilowanym i technikum oraz kształcenie $w$ zakresie rozszerzonym w liceum ogólnokształcącym i liceum profilowanym (Kraków: Wydawnictwo Znak, 2004), 40; Jolanta Choińska-Mika, Paweł Skibiński, Piotr Szlanta, Katarzyna Zielińska, Historia. Poznać, zrozumieć Podręcznik dla liceum i technikum. Część 3. Zakres podstawowy (Warszawa: Wydawnictwa Szkolne i Pedagogiczne, 2009), 37; Rafał Dolecki, Krzysztof Gutowski, Jędrzej Smoleński, Po prostu Historia. Szkoły ponadgimnazjalne. Zakres podstawowy (Warszawa: Wydawnictwa Szkolne 
omawianych epidemii z XVI w., w podręcznikach znajdziemy podstawowe informacje dotyczącej tej pandemii, często o charakterze krótkiego akapitu. Autorzy zgodnie podkreślają rolę czynników tworzących sytuację sprzyjającą gwałtownemu rozwojowi choroby - niedostatku, głodu, przemieszczania się olbrzymich grup ludności i wojska, wybuchających ognisk chorób zakaźnych, jak tyfus czy czerwonka. Przykładem takiej narracji autorskiej jest fragment z podręcznika Piotra Galika z 2016 r., w którym mocno zostały podkreślone długofalowe skutki hiszpanki: „Zatrważające były starty demograficzne. Oprócz strat spowodowanych działaniami wojennymi straszliwe żniwo zebrała pandemia grypy zwanej hiszpanką, pochodzącej z USA (choć początkowo sądzono, ze przyszła z Hiszpanii), skąd została przeniesiona przez amerykańskich żołnierzy do Europy, by w krótkim czasie rozprzestrzenić się na cały świat. Na hiszpankę zachorowało około $500 \mathrm{mln}$ osób (1/3 ludzkości), a zmarło co najmniej $50 \mathrm{mln}$, a więc wielokrotnie więcej niż na frontach Wielkiej Wojny. Do wysokiej śmiertelności przyczyniło się m.in. niedożywienie, będące skutkiem kilkuletnich restrykcji i racjonowania żywności w licznych krajach europejskich. Największe ogniska choroby występowały wśród wyczerpanych wojną żołnierzy frontowych, jednak grypa z łatwością przenosiła się również na ludność cywilną. Tak wielkie straty demograficzne, jakie przyniosła wojna i będąca jej konsekwencją pandemia gryp, spowodowały utratę przez Europę przodującej roli na arenie międzynarodowej, przede wszystkim na rzecz Stanów Zjednoczonych" ${ }^{36}$. Przedstawiane w podręcznikach dane liczbowe dotyczące zachorowań i ofiar mają charakter szacunkowy (od 20 do $50 \mathrm{mln}$ ) i niekiedy są mało czytelne dla uczniów, ponieważ nie wiadomo, czy dotyczą samej Europy, czy też świata ${ }^{37}$. Z drugiej strony spotykamy przykłady uszczegółowienia danych, jak w podręczniku J. Kochanowskiego i P. Matusika z 2004 r.: „[...] tylko w 1918 roku epidemia grypy, tzw. Hiszpanki, pochłonęła prawie $22 \mathrm{mln}$ ofiar $\mathrm{z}$ tego $12,5 \mathrm{mln}$ w Indiach). W USA zmarło na nią 548 tyś. osób, podczas gdy w walkach w okresie I wojny światowej zginęło 114 tyś. Amerykanów" ${ }^{38}$. Znamienne, że w analizowanych podręcznikach nie znajdziemy informacji dotyczących przebiegu i skutków wspomnianej epidemii na ziemiach polskich.

Wielka epidemia hiszpanki $\mathrm{w}$ analizowanych podręcznikach przedstawiona została jako jeden z wielu elementów nowej rzeczywistości wyłaniającej się

\footnotetext{
i Pedagogiczne, 2012) 10; Jerzy Kochanowski, Przemysław Matusik, Człowiek i historia, część 4. Czasy nowe i najnowsze (XIX i XX wiek). Podręcznik dla liceum ogólnoksztatcącego, liceum profilowanego i technikum (Warszawa: Wydawnictwa Szkolne i Pedagogiczne, 2004), 112; Stanisław Roszak, Jarosław Kłaczkow, Poznać przeszłość. Podręcznik do historii dla szkół ponadgimnazjalnych (Warszawa: Wydawnictwo Nowa Era, 2014), 22.

36 Piotr Galik, Zrozumieć przeszłość. Lata 1815-39. Podręcznik do historii dla liceum ogólnokształcącego. Zakres rozszerzony, część 3 (Warszawa: Wydawnictwo Nowa Era, 2016), 353.

37 Np. Szymanowski, Trojański, Historia. Ludzie i epoki, klasa 3, 40.

38 Kochanowski, Matusik, Człowiek i historia, część 4, 112.
} 
z katastrofy I wojny światowej. Autorzy skupili się na globalnym wymiarze epidemii, jej skali i skutkach demograficznych, nie odnosząc się do jej wpływu na rozwój polityki zdrowotnej państw, higieny i medycyny ${ }^{39}$.

\section{Podsumowanie}

Przeprowadzony rekonesans badawczy pokazuje, że wielkie epidemie, których ludzkość doświadczyła na przestrzeni dziejów, mają swoje miejsce w polskich podręcznikach szkolnych do historii wydanych w ostatnich 32 latach. Należy podkreślić, że problematyka wielkich epidemii i generalnie zjawisk z obszaru styku medycyny i życia społecznego jest w narracji badanych podręczników tylko elementem szerszych obrazów, na przykład czarna śmierć - kryzysu XIV w., a hiszpanka kryzysu po I wojnie światowej. Przeprowadzona analiza umożliwia sformułowanie kilku końcowych wniosków:

1. Najpełniej pod względem objętości treściowej i różnorodności przekazu zaprezentowała została średniowieczna epidemia czarnej śmierci z XIV w., co wydaje się zrozumiałe ze względu na skalę, znaczenie, bliskość geograficzną i silne zakorzenienie tego zjawiska w przekazie dydaktyczno-historycznym. Czarna śmierć została pokazana z szerokim uwzględnieniem genezy zjawiska oraz wielokierunkowych konsekwencji demograficznych, społecznych i ekonomicznych.

2. Epidemie, które miały miejsce w okresie antyku, tylko w niewielkim stopniu znalazły swoje odzwierciedlenie w analizowanych podręcznikach. Wyjątkiem są podręczniki autorstwa Marka Ziółkowskiego, w których Autor szerzej scharakteryzował epidemie z czasów cesarstwa rzymskiego.

3. W przypadku XVI-wiecznych epidemii w Nowym Świecie jak i tzw. hiszpanki uczeń otrzymuje zdecydowanie elementarne informacje, które nie zawsze są ścisłe i precyzyjne. Szczególnie w przypadku wspomnianych epidemii w Nowym Świecie brakuje odniesienia do najnowszych ustaleń naukowych.

4. Elementy obudowy dydaktycznej (mapy, tabele, ilustracje) pojawiają się przede wszystkim w treściach poświęconych czarnej śmierci, a także, w mniejszym stopniu, tych dotyczących XVI-wiecznych epidemii na kontynencie amerykańskim.

5. W analizowanych podręcznikach brak wyraźnie uchwytnej zmienności w sposobie prezentacji wymienionych zjawisk na przestrzeni omawianego okresu. Patrząc z perspektywy współczesnej nam pandemii, można odczuwać pewien niedosyt po przeprowadzeniu powyższej analizy. Być może zapomnieliśmy już

\footnotetext{
39 Warto zaznaczyć, że w popularnych podręcznikach z lat dziewięćdziesiątych brak odniesień do grypy hiszpanki, zob. Anna Radziwiłł, Wojciech Roszkowski, Historia 1871-1939. Podręcznik dla szkół średnich (Warszawa: Wydawnictwo Szkolne PWN, 1998); Grażyna Szelągowska, Historia 3. Dzieje nowożytne i najnowsze 1870-1939 (Warszawa: Wydawnictwa Szkolne i Pedagogiczne, 1998).
} 
o dramatycznych zmaganiach minionych pokoleń walczących ze śmiercionośnymi epidemiami, które stały się tylko suchymi informacjami na stronach podręczników historii. Dzisiejsze, nie mniej dramatyczne, doświadczenia być może dadzą impuls do szerszego uwzględnienia problematyki dziejów zdrowia publicznego, higieny, historii medycyny w nowych edycjach podręcznikowych.

\section{Michał Kosznicki}

\section{Epidemics and pandemics in selected Polish school history textbooks for secondary schools after 1989}

The paper presents an analysis of the presentation of major epidemics (pandemics) in the history of mankind in Polish history textbooks for secondary schools published between 1989 and 2020. A qualitative study was carried out on a sample of forty-four textbooks and concerned issues such as: epidemics in antiquity, the so-called "Black Death' from 1346 to 1353, epidemics in the New World during the period known as the Age of Discovery, and the Spanish flu (the Great Influenza Epidemic) of 1918-1920. This analysis made it possible to formulate conclusions: 1) the medieval "Black Death" epidemic of the XIV th century was presented most fully, both in terms of content and diversity of coverage. This is understandable because of the scale, significance, geographical proximity, and strong roots of this phenomenon in history-teaching literature. "The Black Death" was shown with a broad consideration of the genesis of the phenomenon and its multidirectional demographic, social and economic consequences; 2) the epidemics that took place in the period of antiquity were only to a small extent reflected in the textbooks analyzed. The exception are textbooks by Marek Ziółkowski (editions 1999 and 2002), in which epidemics from the times of the Roman Empire are described in greater detail; 3 ) in the case of the XVI ${ }^{\text {th }}$-century epidemics from the New World, as well as the Spanish flu, the school reader received what was definitely elementary information, which was not always accurate and precise, without references to the latest scholarly findings; 4) elements of teaching support (maps, tables, illustrations) appeared mainly in the contents dedicated to the "Black Death" and, to a lesser extent, to the XVI ${ }^{\text {th }}$-century epidemics on the American continent; 5) in the textbooks analyzed, there was no clear variation in the way the above-mentioned phenomena were presented in the course of the period discussed. 